\title{
原著
}

\section{Paget 病の剥離細胞診}

\author{
——特に悪性黒色腫との鑑別——
}

獨協医科大学病理*, 外科**, 病院病理***

山田喬* 信田 重光** 日高 知昭** 佐藤 豊彦***
国立がんセンター細胞診名古屋市立大学医学部中検病理
上井良夫柴田 偉雄

県西部浜松医療センター外科*, 中検病理**
石垣 実弘* 室久敏三郎* 岡本 一也 ${ }^{* *}$ 土井 久平**
千葉県がんセンター病理*, 細胞診**
田中 昇* 池田 栄雄**

賛育会病院外科*, 細胞診**

垣花 昌彦* 浦崎 政浩**

\section{1. はじめに}

1874 年 Sir James Paget ${ }^{15)}$ が初めて癌と関係づけて

Cytodiagnosis of the Mammary and Extramammary Paget's Diseases-With Special Reference to Differentiation from Malignant Melanoma

Takashi YAMADA, M.D., F.I.A.C., Shigemitsu SHIDA, M.D., F.I.A.C., Tomoaki HIDAKA, M.D. and Toyohiko SATO, C.T., J.S.C., I.A.C.

Dept. of Path., Surg. and Hosp. Path., Dokkyo Univ. Sch. of Med.

Yoshio UEI, M.D., M.I.A.C.

Dept. of Diag. Cytol., National Cancer Center

Takao SHIBATA, M.D., M.I.A.C.

Dept. of Hosp. Path., Nagoya City Univ. Sch. Med. Mitsuhiro ISHIGAKI, M.D., Binzaburo MUROHISA, M.D., Kazuya OKAMOTO, M.D., and Kyuhei DOI, C.T., J.S.C., I.A.C.

Dept. of Surg. and Hosp. Path., Hamamatsu Medical Center

Noboru TANAKA, M.D., F.I.A.C., and Hideo IKEDA, C.T., J.S.C., I.A.C.

Dept. of Path. and Diag. Cytol., Chiba Pref. Cancer Center

Masahiko KAKIHANA, M.D., and Masahiro URA. SAKI, C.T., J.S.C., I.A.C.

Dept. of Surg. and Lab. of Diag. Cytol., Sanikukai Hospital

昭和 53 年 5 月 15 日受付
記載したといわれる Paget 病は, その初めの報告に おける標題が “On disease of the mammary areola proceding cancer of the mammary gland" と記載 されたことより明らかなごとく，当初は前癌状態と考え られる病変である. 通常は乳頭表面における湿疹様の病 変であり, その発生初期には腫瘤を形成せず, 特有な形 態を示しながら異型細胞が上皮内に増殖進展する病変で あることはよく知られている.

しかしその後の研究により,この病変は決して前癌性 病変ではないことが明らかになり，その病変に関する議 論はむしろその組織発生的な由来に関する問題 ${ }^{18,19)}$ に向 けられてきた. すなわち皮膚における特有な病変はその 後に発生する乳腺内の浸潤癌の先行病変 (初期病変) な のか, あるいは乳管末梢上皮から発生した癌が二次的に 乳頭皮膚内に浸潤発育するのかといら問題であろう.

いずれの発生機序を考えようとも，それらの報告にみ る乳頭皮膚内における病変, すなわち Paget 細胞を中 心とした病理組織学的所見には大きな違いはないように 思われる. そしてこの Paget 病の診断に際しては, 皮 膚生検が重要な手段となることは論をまたない。他方, 細胞診も当然のことながらこの診断に有効な手段である 
表 1 Paget 病症例の剝離細胞像

\begin{tabular}{|c|c|c|c|c|c|c|c|c|c|c|}
\hline 例 & $\begin{array}{l}\text { 年龄 - 性 } \\
\text { 発生部 位 } \\
\text { 所属病院名 }\end{array}$ & $\begin{array}{l}\text { (1) } 78 \text { 歳列 } \\
\text { 㓌筫 } \\
\text { 多市火 }\end{array}$ & 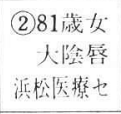 & $\begin{array}{l}\text { (3) } 55 \text { 筬文 } \\
\text { 乳 腺 } \\
\text { 国立がんセ }\end{array}$ & $\begin{array}{l}\text { (4) } 67 \text { 歲久 } \\
\text { 乳 腺 } \\
\text { 国立がんセ }\end{array}$ & $\begin{array}{l}\text { (5) } 40 \text { 筬久 } \\
\text { 乳 腺 } \\
\text { 名 } 1 \text { 大 }\end{array}$ & $\begin{array}{l}\text { (6)77歳久 } \\
\text { 乳 腺 } \\
\text { 千葉かんセ }\end{array}$ & $\begin{array}{l}\text { (7) } 32 \text { 歲女 } \\
\text { 乳振 } \\
\text { 独協原大 }\end{array}$ & $\begin{array}{l}\text { (8) } 41 \text { 慽女 } \\
\text { 乳腺 } \\
\text { 浜松医療七 }\end{array}$ & $\begin{array}{l}\text { (9) } 45 \text { 歳多 } \\
\text { 乳腺 } \\
\text { 替去会满 }\end{array}$ \\
\hline 沗 & 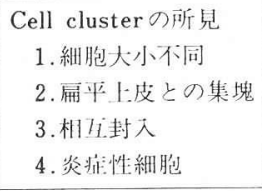 & $\begin{array}{l}+ \\
- \\
+ \\
+\end{array}$ & $\begin{array}{l}+ \\
H \\
H \\
H\end{array}$ & $\begin{array}{l}+ \\
- \\
+ \\
+\end{array}$ & $\begin{array}{l}+ \\
- \\
- \\
+\end{array}$ & $\begin{array}{l} \pm \\
H \\
H \\
H\end{array}$ & $\begin{array}{l}H \\
+ \\
H \\
+\end{array}$ & $\begin{array}{l}\text { H } \\
+ \\
+ \\
+\end{array}$ & $\begin{array}{l}H \\
- \\
H \\
+\end{array}$ & $\begin{array}{l}H \\
- \\
H \\
H\end{array}$ \\
\hline 月 & 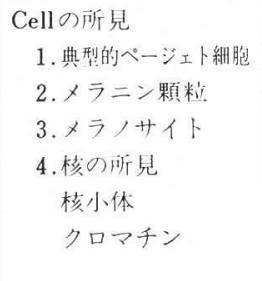 & $\begin{array}{c}- \\
H \\
H \\
H \\
\text { 中r } \\
\text { 顆精状 }\end{array}$ & $\begin{array}{l}\text { 大, 多 } \\
\text { 粗 大 } \\
\text { 顆精状 }\end{array}$ & $\begin{array}{c}\text { 小 } \\
\text { 微 細 } \\
\text { 顆粒状 }\end{array}$ & $\begin{array}{l}+ \\
- \\
-\end{array}$ & $\begin{array}{c}\text { 中 } \\
\text { 顆䊉状 }\end{array}$ & $\begin{array}{c}+ \\
+ \\
+ \\
\text { 大 } \\
\text { 顆敉状. }\end{array}$ & $\begin{array}{c}\text { H } \\
- \\
- \\
\text { 中' } \\
\text { 粗, 大 } \\
\text { 顆粗状 }\end{array}$ & $\begin{array}{c}- \\
+ \\
- \\
\text { 大 } \\
\text { 粗大毛状 }\end{array}$ & $\begin{array}{c}- \\
\text { Ht } \\
+ \\
\text { 大 } \\
\text { 䉼 大 } \\
\text { 顆粉状 }\end{array}$ \\
\hline
\end{tabular}

と考えられている．無用な外科的侵襲を避けるためにも 細胞診は有用であるう。

しかし,この病変からの剝離細胞像に関する記載はき わめて少なく，大部分は症例報告の規模の報告しかな い.その理由の一部は, この病変の発生頻度が低く（発 見された乳癌例の 1 〜 $3 \%$ であるといわれる る ${ }^{8)}$ ), 各施設 単独の自験例を対象とする限り，多数例を比較検討する 機会に恵まれないためと思われる。

そこで，われわれは 6 施設が協同して症例を集め，そ れらを比較検討した結果, 若干の興味ある知見を得た。

特記すべきは，この病変からの剝離細胞はしばしばメラ ニンを含み，剝離細胞学的にも悪性黒色腫と類似する場 合があるということである. 両者の鑑別診断の要点を中 心に報告したい.

\section{2. 症 例}

細胞を擦過あるいは吸引して採取した症例, およびそ の発生部位は表 1 のごとくで, 乳腺外に発生した Paget 病も加えて検討した, 乳腺 Paget 病 7 例 (図 1,2 ), 乳 腺外 Paget 病 2 例（陰囊, 陰唇各 1 例, 図 3,4 ) が対 象例であり, 症例 4 を除き組織像とを対比しつつ検討し た. 症例 4 のみは, 他院で外科的に切除されたため, 組 織学的には直接確かめ得なかったが, 肉眼的にも, 病理 組織学的にも他院で確診された例である.

病理学的には症例 3, 6 9 は, 皮膚病変のみならず乳 腺内に腺癌が認められた例で（そのような例を Pagetoid 病という者もある ${ }^{18)}$ ) あるが、いずれも剝離細胞は皮膚 病変から得られたものである.

細胞採取後, 直ちに $1: 1$ エーテル・アルコール固定,

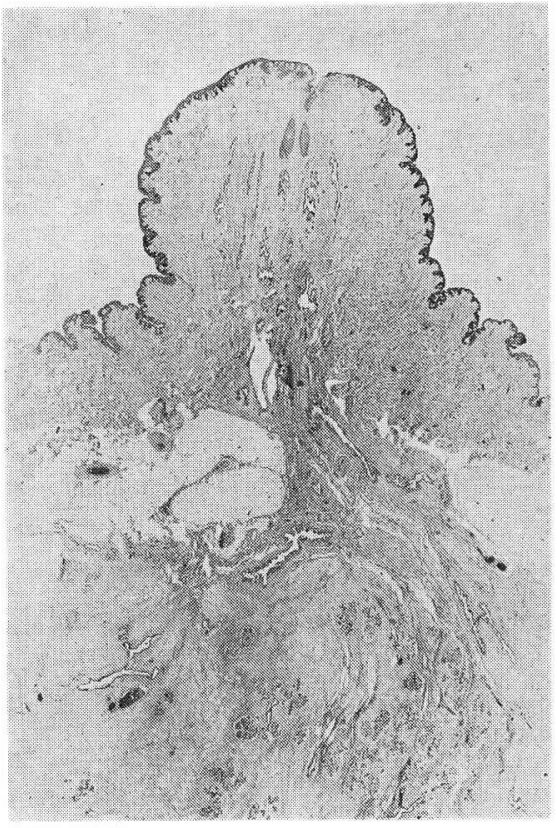

図 1 乳頭部 Paget 病 上皮内に癌細胞が限局しているため腫瘤形成 はない $(\mathrm{H}-\mathrm{E}$ 染色 $\times 1.3)$.

あるいは, 乾燥後, アルコール固定を行い, パパニコロ ウ染色あるいは，ギムザ染色を行った．少数例は PAS 染色も行った.

\section{3. 剝離細胞所見}

\section{細胞塊としての特徵}

まず全例にリンパ球を中心とした炎症性細胞が，異型 上皮細胞とともに採取された.これは組織学的背景と一 


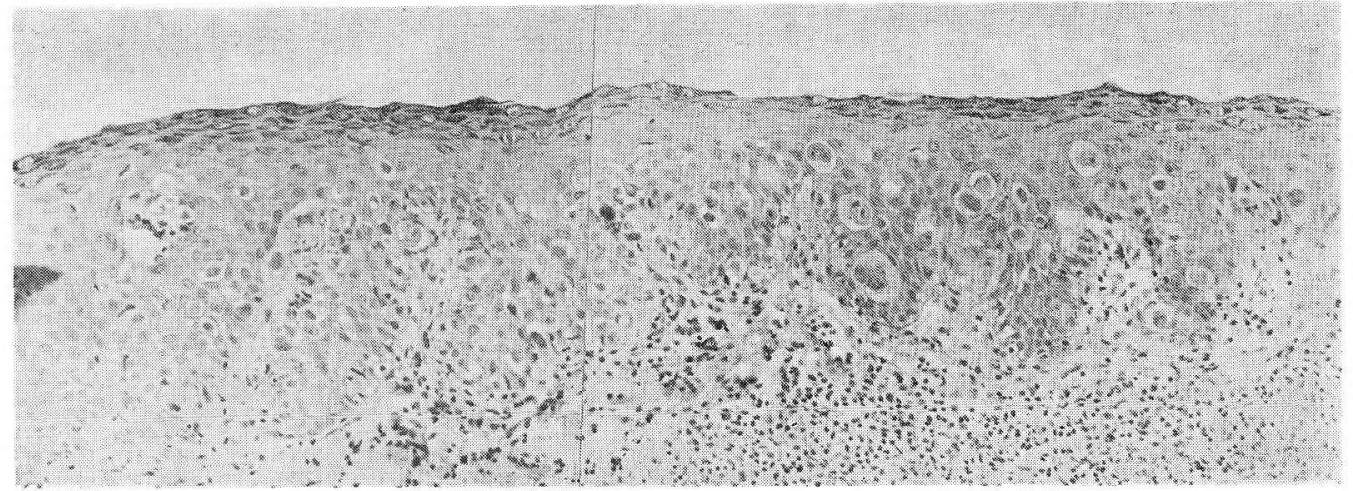

図 2 乳頭部 Paget 病

大型の Paget 細胞が浸潤発育している $(\mathrm{H}-\mathrm{E}$ 染色 $\times 100)$.

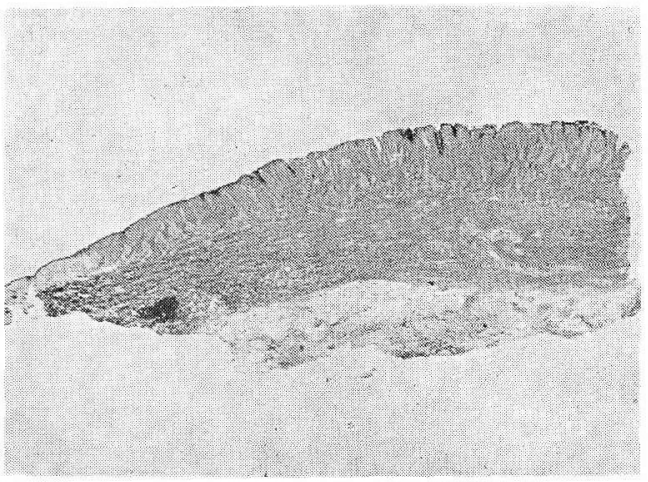

図 3 陰唇部 Paget 病 $(\mathrm{H}-\mathrm{E}$ 染色 $\times 2.2)$

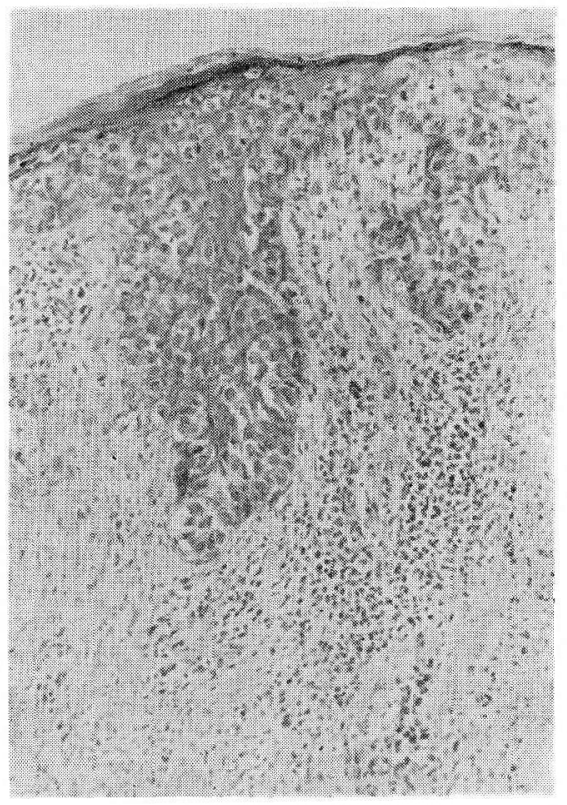

図4図3の強払大 $(\mathrm{H}-\mathrm{E}$ 染色 $\times 100)$

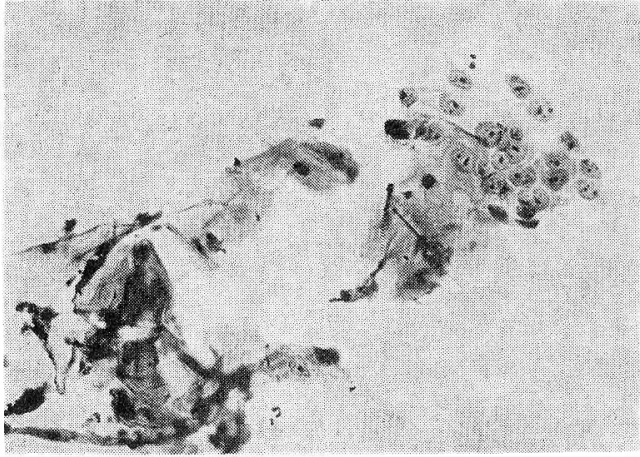

図 5 扁平上皮細胞と集塊老形成して剝離した異型細胞 (Pap. 染色 $\times 400)$

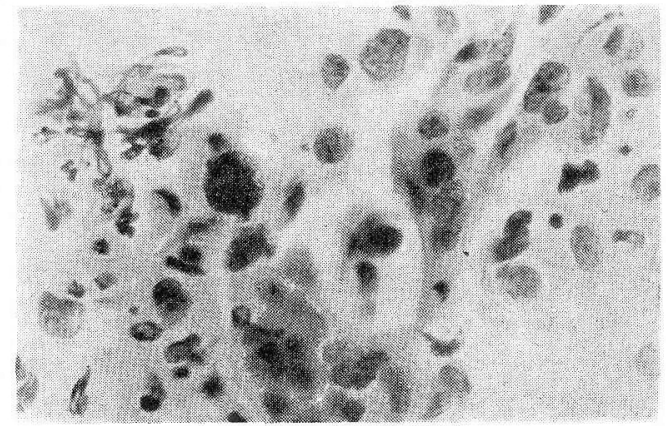

図 6 扁平化した右上の扁平上皮細胞上大型異型細胞が 同一細胞の集団に混在

この例では，核小体は日立たず，核膜も薄くクロマチン 顆粒の)増加がみられる（Pap. 染色 $\times 400)$

致する所見である，異型細胞は，通常扁平上皮細胞と混 在して剝離するが，4/9 例において，扁平上皮細胞と異 型細胞とが一塊となって剝離し細胞塊となっているのを 認めた. 前者はしばしば圧排されて紡錘状の形態を示し た.そして，それらの細胞群はまれならず, 乾燥しやす く，それゆえに角化傾向がないにもかかわらず，細胞質 


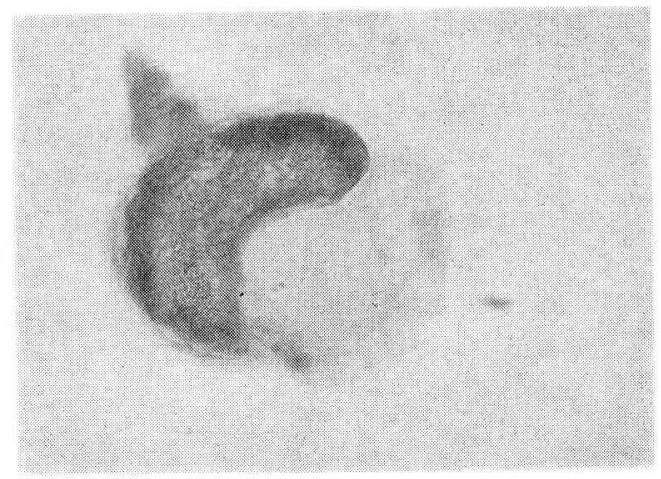

図 7 Paget 細胞

偏在した核之広い細胞質。この祉例の細胞質はPAS 陽 性 $(\mathrm{H}-\mathrm{E}$ 染色 $\times 1,000)$.

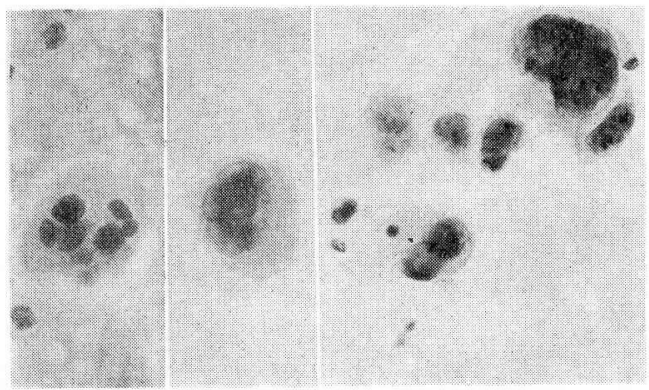

図 8 左側の $2 つ の$ 細胞は Paget 病症例に見られた多 核細胞

いずれもあまり大型な多核細胞ではない，右側の写真は Paget 細胞在含屯細胞核の大小不同走示 (Pap. 染色 $\times 400)$.

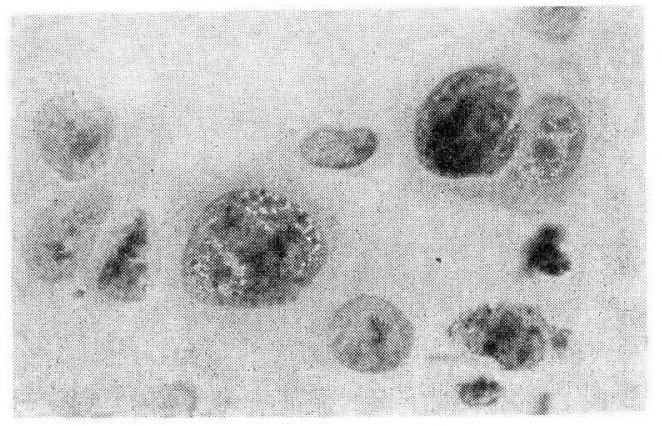

図 9 Paget 病細胞にみられた大型異型細胞

(Pap. 染色 $\times 1,000)$.

はオレンヂ Gに染まりやすかった（図 5,6).

異型細胞は全症例において，程度の差はあるが，その 大小不同がかなり著明に認められた。しかし，この病変 の特徴的な大型の Paget 細胞（図 7,8） は3/9 例に見 られたにすぎない. それ以外の症例では大型な異型細胞 でも，図 9 に示すごとく, 細胞の中心に核があり, 細胞

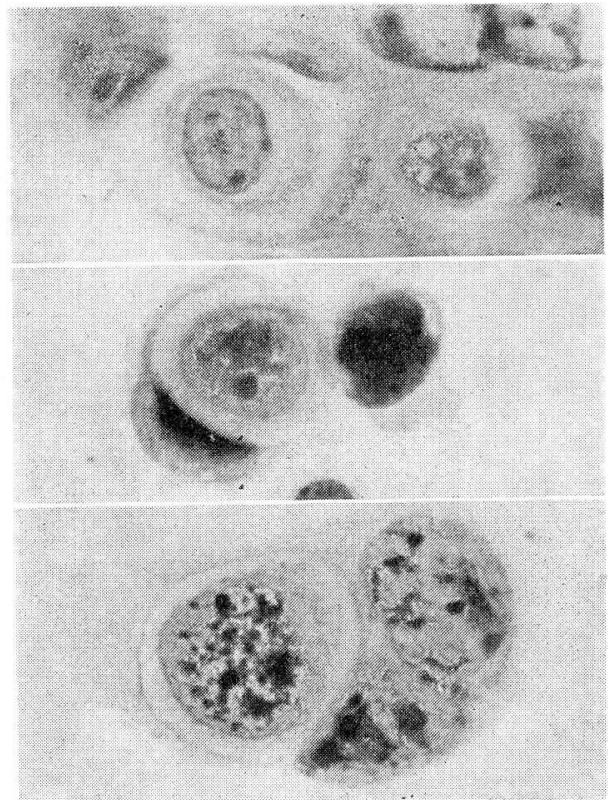

図 10 相互封入を示寸 Paget 病症例の異型細胞群 封入された異型細胞の細胞辺縁は不明瞭(Pap. 染 色 $\times 1,000)$.

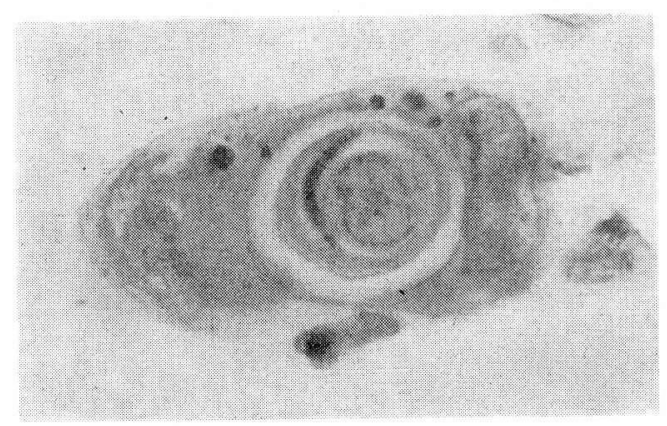

図 11 一見癌真珠を思わせる細胞相互封入像 細胞質に大小の)メラニン顆粒が見られる(Pap. 染色 $\times 1,000$ ).

質の比較的せまい細胞像を示した. いずれにしても通常 の乳癌細胞に比べて, anisocytosis, anisonucleosis が 著しく,ことに Paget 細胞のある例ではその程度はと くに著しかった.

異型細胞集団の形態のなかには，細胞相互封入（mutual inclusion) 老頻回に認めた (8/9 例). 多くは図 10 に示すような封大像であるが，まれには図 11 にるよ うな多数の異型細胞が相互に巻きあらように封入し, 癌 真珠類似の構造を示す例があった（症例 9 ). この相互 封入した細胞の間隙は，あまり開大せず，とくに封入さ れた内側の細胞の辺縁は，しばしば不明瞭で毛ばだって いる例が多かった。 


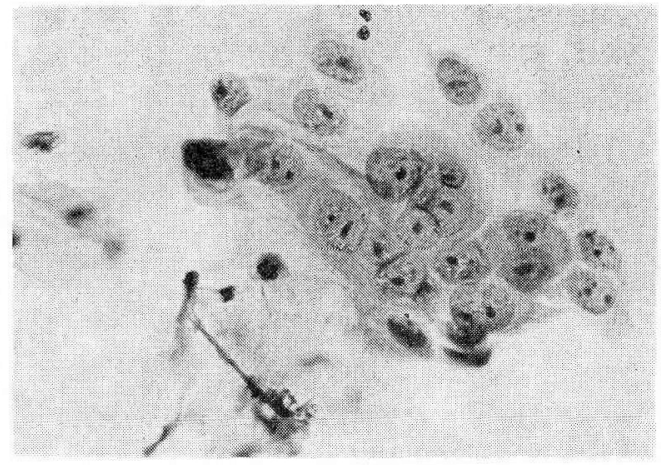

図 12 核小体の大きいク口マチン量の少ない異型細胞 一見腺癌細胞に似ているが核膜は薄い(Pap. 染色 $\times 400)$ ．

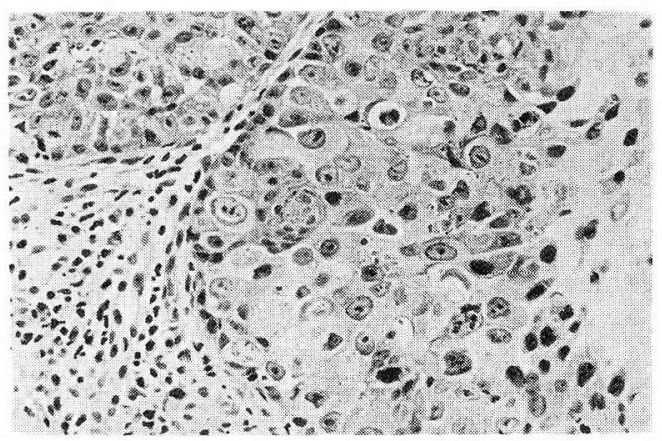

図 13 この組織から図 12 に示寸異型細胞が剝離した ( $\mathrm{H}-\mathrm{E}$ 染色 $\times 400)$.

\section{個々の細胞形態の特徵}

Paget 細胞は非常に大型で，同時に軳脱する異型細胞 より飛びぬけて大きく, 多くの核は偏在し, 粗大顆粒状 の明るい細胞質を持っていた（四７），核は顆粒状のク ロマチンが増量し，一般に核膜は薄く，核小体は症例に よりかなり異なる。この細胞の発見頻度は，意外と低く (先に示したごとく $3 / 9$ 例)*, したがって, Paget 細胞 を発見できない例でも，他の細胞学的所見より Paget 病 を推定された例もある。この大型の広い細胞質は PAS 染色で染まった（2例に PAS 染色を行ったのみであ り，他の 7 例については不明. ジャスターゼ試験も行っ ていない).

大型の Paget 細泡以外刀異型細抱さ症例儿よりかな り異なるが, 図 12,13 に示すごとく,きわめて核小体が 大きく，クロマチン顆粒はむしろ増量しない例から，図 9 にみられるよらな比較的小型な顆粒状のクロマチンが 著しく増量した例があり，それらにはかなりの差がみら れた. 寸なわち症例により腺癌を思わせ，また扁平上皮

*このような大型細胞は標本製作の際に破壊されやすいかも しれない。

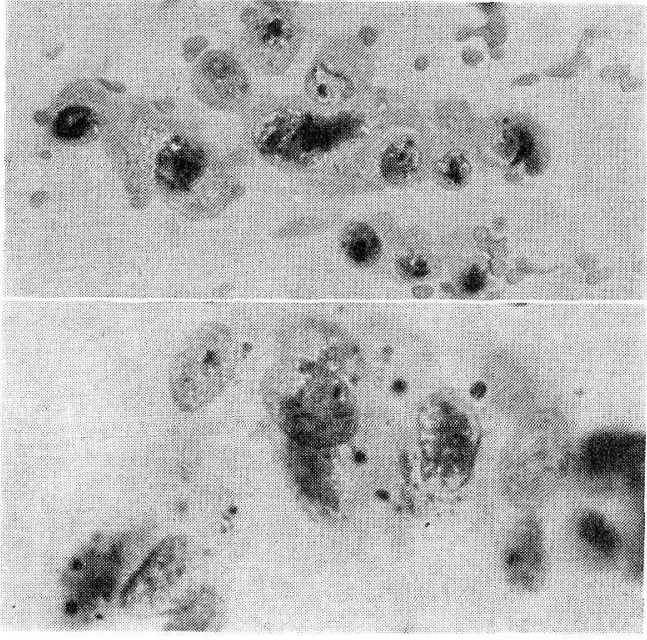

図 14 各種メラニン沈着像

その分布や顆粒の大きさは細胞に上り異なる(Pap. 染色 $\times 1,000)$.

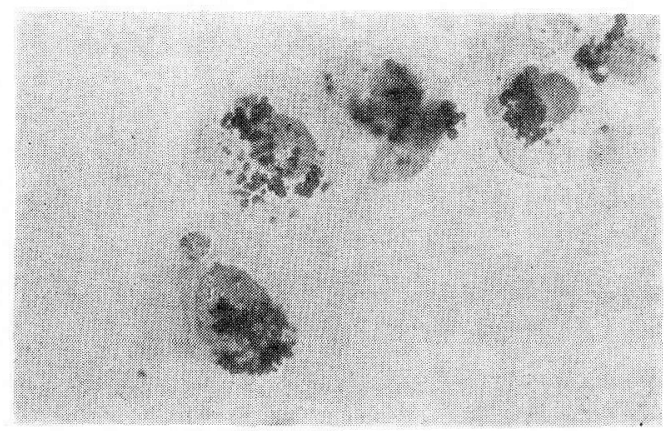

図 15 最も密度高く沈着したメラニン顆粒像

このような細胞は悪性黑色腫とまちがわられや寸に

(Pap. 染色 $\times 1,000)$.

癌に類似する核内構造を示したしかしこの差は，乳腺 内に浸潤性の腫瘍を形成しているか否かとは無関倸であ った．核内空泡は1例にもみられなかった。

多核細胞も2 例に認められたが，いずれも大型ではな く，図8の左に示すような多核細胞であった。

\section{メラニン顆粒とメラノサイト}

特記すべき所見はこれらの異型細胞の細胞質内に高頻 度にメラニン顆粒を認めたことである。組織学的にも Paget 細胞内にメラニンの存在を指摘した論文むある が5，それが剝脱した細胞の形態をみると症例によりか なりの差があり, Paget 細胞以外の異型細胞にも認めら れ，その発見頻度は $6 / 9$ 例である。 そしてメラニン顆料 の大きさや形も症例により，まちまちである。図 15 に 見るように，多数のメラニン顆粒を認める例をあるが， 多くは図 14 の程度にメラニン顆粒を認め, 図 11 のごと 


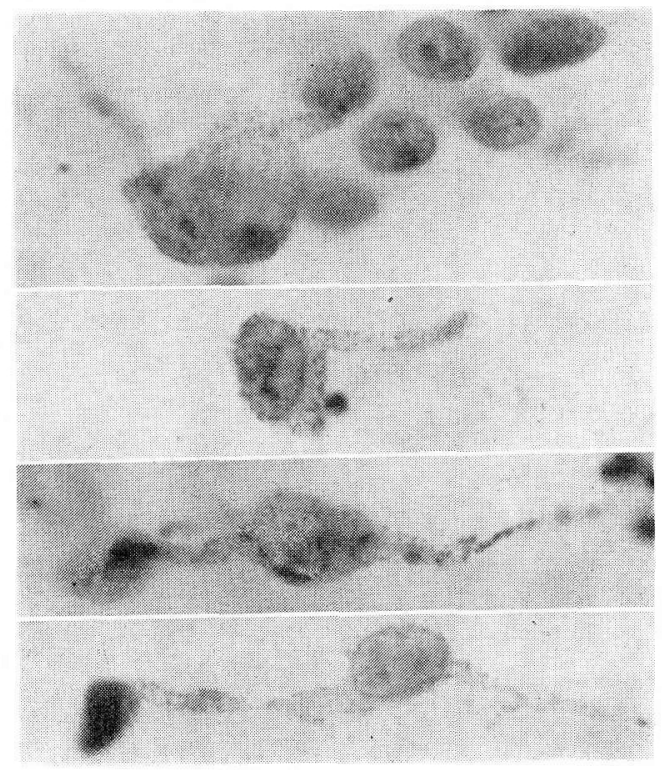

図 16 各種のメラノサイト

最上段のメラノサイトの突起は下の異型細胞群のなかい 雨入されている (Pap. 染色 $\times 1,000)$.

き相互封入細胞にも，かなり大型な顆粒が存在した（と くに Giemsa 染色ではメラニン顆粒が黒く染まるので 見やすい).

上記の異型細胞とは別に図 16 に示すごとき，樹枝状 あるいは尾状に細胞質突起を示すメラノサイトが $4 / 9$ 例 に見出された.この細胞注症例 $1 ， 3 ， 6 ， 9$ に見出され， とくに肉眼的に色素沈着の多い㓌囊 Paget 例に高頻度 に認めた。このメラノサイトは癌細胞と密接な関係があ り，まったく遊離散在性となって癌細胞周同に認められ る場合が多いが，図 16 の最上段のメラノサイトに見る ごとく, 癌細胞塊（シート）にその突起を挿入している 像が 1 力所ではあるが観察された.

\section{剝離細胞像における悪性黒色腫との鑑別}

自験例からみた悪性黒色腫 ${ }^{21,22)}$ との鑑別点は以下のご とくである.

1. Paget 病の細胞群の多くは, 榜および細胞の大小 不同が著明でかなり大きなシートを形成する場合があ る. 細胞の大小不同の強い悪性墨色腫例 (amelanoic or hypomelanoic melanomaはこの型に多い) では, 細胞 間の結合性が弱く，組織の上では epitheloid arrangement と呼ばれるくらいに細胞間が開大している. した がってその剝離細胞は大きなシートを形成することはま ずない.また Paget 病の異型細胞群と扁平上皮細胞群 が，塊となって剥脱することがあるが，このような形態 は悪性黒色腫ではみられない.
2. 細胞相互封入像は両者にみられるが, Paget 病の 症例では，封入された細胞の辺縁がけばだっており，ま た相互に密に接触する例が多い。

3. 悪性黒色腫の一型に, まったく紡鍾型細胞よりな る型があるが21,22)，そのような細胞型は Paget 病症例 にはない。

4. 核内空泡 ${ }^{22)}$ は Paget 症例にはまったく認められ ない。

5. メラニン顆粒は，両者の細胞質にみられるが，覀 性黒色腫細胞に見るような細胞質内に充満するメラニン 顆粒像は, Paget 病症例にはみられない。

6. メラノサイトは Paget 病症例の半数弱にみられ たが，悪性黒色腫例では目立たない（自験例では発見で きなかった).

以上の所見が両者の鑑別点である.しかし自験例では 上皮内に限局して増殖している malignant melanoma in situ 例が含まれていないので，これらの所見は浸潤 増殖性の悪性黒色腫例との比較である。

\section{4. 考察}

Paget 病に関する剥離細胞診の報告は, 従来少なく,

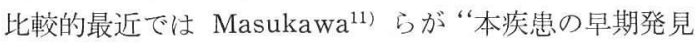
のために細胞診が役に立ち得る”ことを強調したにすぎ ない.

Ashikari ら 2)によると, 発見された時期に, この表 皮内病変とともに, 乳腺内に浸潤性腫瘤を認める例と, 皮膚病変のみの例の比率は $113: 96$ であり, 坂本ら ${ }^{18)}$ それは $17: 11$ である.これらの発見例すべてに細胞訬 が応用されたか否かは不明であるが，従来の成績では， この疾患の過半数が早期に発見されたとはいいがたい. しかも Paget 病には, このほかにも組織発生的に問題 がある.

というのは, 従来 Paget 病と診断された症例は, す ベてが皮膚から発生した癌であり，これが二次的に乳腺 内に進展するとは限らず，逆に乳腺導管末梢部の上皮か

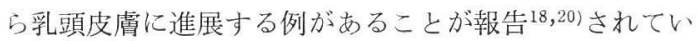
るからである。したがってその早期診断の意味づけに関 しては現在のところ必ずしも容易ではなく, その意味 で，細胞診による早期診断の効用を強調しすぎることは 当を得ていないむしろ臨床の実際では, 他の体表の癌 病変と同様に, 組織学的診断の前の一次スクリーニング の手段としての細胞診の重要性を認めるべきであるら. そのためには, 本疾患の剝離細胞像を整理し, 通常の乳 癌と区別して診断し得る細胞学的規準を確立することは 


\section{有意義であろう.}

本研究は, 当初このような見地に立って出発したので あるが，9例の症例を通覧したところ，予期しない知見 (Paget 病症例の乳頭あるいは皮膚から擦過塗抹標本に おける異型細胞には高頻度にメラニンを含有する）を得 たので, これを中心として報告した.

本来 Paget 病の病理組織診断においても, そのある 組織型は悪性黒色腫と類以してお $り^{1,6,11)}$, その初期の表 皮に限局したある型の悪性黒色腫に対して, pagetoid malignant melanoma in situ (Clark) と診断される場 合がある.したがって Paget 病と悪性黒色腫との鑑別 が剝離細胞学的にも問題があるということは当然の結果 であろう、しかし本論文で示したように, 両者の区別 は, 種々の細胞学的特徵を知ることにより可能であろう と思われる. その意味でも病理組織学的診断の前に剝離 細胞診を行う価值がある（もっとも乳頭部には悪性黒色 腫はきわめてまれである, とどの成書にも記載されてい るから, むしろその点では乳腺外の Paget 病の場合に 強調されるべきであろう).

Paget 病症例の異型細胞内になぜメラニン顆粒が沈着 するのであろうか?

Culberson $^{6)}$ は, Paget 病症例の 10/25 例の腫瘍組織内 にメラニンの沈着を認めたと報告しているが, 本報告例 では 6/9 例の異型細胞にメラニン沈着をみた.このメラ ニンの沈着機構について推定するためには, まず Paget 病症例における異型細胞の由来を明らかにせねばならな い. 報告によるとその由来に関する定説はいまだ得られ て抢らず, 乳腺導管末梢細胞に由来すると推定する者 $4,7,9,10)$ と, 表皮の扁平上皮細胞に由来すると推定する者 13,16,17) が大勢を占めている.

電顕的検索によると, これらの上皮内癌細胞の細胞間 には，上皮細胞の結合機構である desmosome が明らか にされている，それゆえまずは上皮性細胞であることは 疑いない. 興味あることは, Paget 細胞の一部と扁平上 皮細胞との間にも desmosome が見られるという所見で ある ${ }^{13,17)}$. 本論文で報告した Paget 病症例における異 型細胞と扁平上皮細胞がときに一塊となって結合状態で 剝脱するという所見の裏づけの知見であるように思われ る.

さらに Medenica と Sahihi ${ }^{13)}$ は電顕的観察におい て, desmosome, 細胞膜の形態, tonofilament bundle などの超微形態的特徵より, 表皮における keratinocy to に Paget 細胞は由来すると推定している. 一方乳腺導 管末梢由来を裏うける分泌顆粒を示し, その形態よりエ ククリン腺由来を示唆する知見を報告する者 $4,7,10)$ も

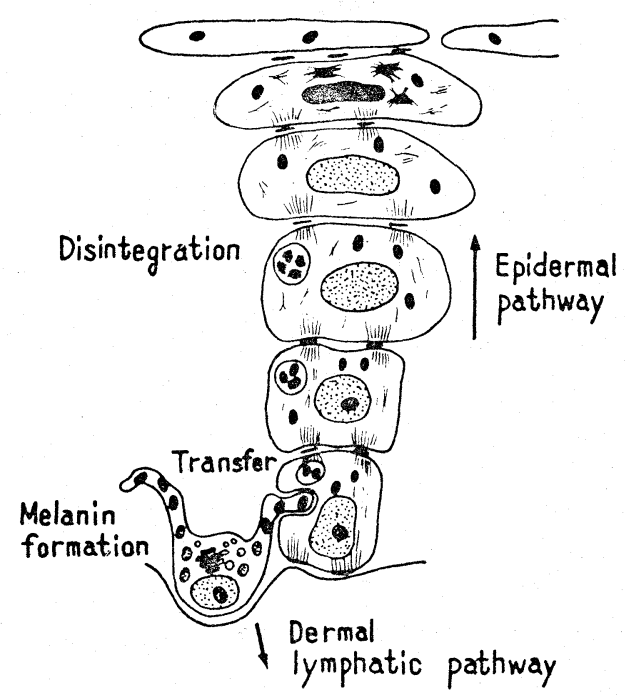

図 17 上皮細胞内メラニン沈着機構の推定シェーマ (清寺, 棚橋 ${ }^{19)}$, 1972)

る. 乳腺導管末梢由来説をも否定するわけにはゆかない ようである.

他方, 完全な証明は必ずしも無いが, たいへん思い切 った意見も報告されている.すわなち Paget 細胞は表 皮におけるメラノサイトの変性した像であり, 腫瘍細胞 ではないといら説 ${ }^{14)}$ である. その根拠として, Paget 病 に侵された表皮の部分には限局的に突然基底層のメラニ ン沈着が消失しているということ，また Paget 細胞そ のものが表皮を超えて浸潤性発育を示す例がないこと， さらにこの疾患における乳頭の崩壊は, この Paget 細 胞の変性の進行と皮下の各種線維組織の変性によるもの であるとの主張を表明している. そして Paget 細胞の 細胞質内にメラニン沈着についても言及しているが，も しメラノサイト由来と考えればメラニンの存在は当然で あろら。

電顕的観察のすべては，このメラノサイト由来説を否 定している ${ }^{9,13,16,17,18)}$. しかし，このメラノサイト由来 説は種々な点で著者らに示唆を与えた. まずメラノサイ トが何んらかの過程で Paget 細胞内のメラニン沈着と 関係してはいないかという点. そして次に Paget 病の 剝離細胞像が悪性黒色腫のそれと類似することの意味に ついて, その細胞発生学的な観点から検索することの必 要を考えさせられた点である.

これらの報告, ならびに自験例における剝離細胞所見 を総合して, われわれは Paget 病症例におけるメラニ ン沈着機構は表皮の扁平上皮細胞におけるそれと類似で はないかと考えるに至った。 
文献によると，表皮の扁平上皮層に抢けるメラニン沈 着機構については, 種々の基礎的解析や憶測がなされて いる. そのなかで最近, 清寺, 棚橋 ${ }^{19}$ が報告した論文中に 描かれたシェーマはきわめて明快にその機構を説明して いる(図 17).すなわち表皮細胞内へのメラニン沈着は， メラニン産生細胞であり, 表皮内に存在するメラノサイ 卜の樹枝状突起が表皮の扁平上皮細胞内に挿入されて注 入されるか，あるいは樹枝状突起が表皮細胞により喰食 されてメラニンが細胞内に取り込まれるという説であ る. そしてこの現象についての実験的な傍証の報告 $3,5,8)$ も引用している.

そこでもし，この表皮の扁平上皮細胞へのメラニン沈 着機構が事実ならば，同じく表皮内に存在し，それ自身 メラニン産生能のない Paget 病症例の異型細胞へのメ ラニン沈着も，これと同じ機構が考えられてしかるべき ではなかららか?

本報告でメラノサイトが $4 / 9$ 例, 約半数の症例に見出 されたことは Paget 病症例の異型細胞とメラノサイト との関係を思わせる. そして 1 例ではあるが, 異型細胞 のシート内にメラノサイトの突起が挿入されている像 （図 16 の最上段の写真）が見出されたことは偶然とは思 われない。

\section{5. 結 語}

Paget 病症例（乳腺 7 例, 陰唇 1 例, 陰囊 1 例）につ いて, その剝離細胞像を検討し, その特徵的な細胞所見 を整理した. とくにその細胞質内に高頻度にメラニンが 認められることを強調し，その細胞像と悪性黒色腫のそ れとの相異点について報告し, 加えてそのメラニン沈着 機構について1つの推定を試みた.

本研究に際し, 対象例の病理組織学的検索のご便宜を与えら れた同愛記念病院病理, 福島範子先生, および国立がんセンタ 一病理, 広田映五先生に謝意を表します. なお本論文の内容は日本臨床細胞学会第 19 回総会 (盛岡) に て発表した。

\section{Summary}

In the present paper, the cytodiagnostic findings of 9 patients, having 7 mammary and 2 extramammary Paget diseases each, are discussed with emphasis on their cytologic features and mechanism of melanin pigmentation into the cytoplasma of cancer cells. In the smear specimens collected by scraping or needle-aspiration, large cancer cell clusters occasionally mixed with benign epi- dermal cells, anisonucleosis, large typical Paget's cells with wide cytoplasma, melanin-pigmentation into the cytoplasma and occasionally presence of melanocytes were characteristic for the cytodiagnostic features of the present diseases.

It is proposed that melanin pigmentation into the cytoplasma of the cancer cells is presumably induced through the same mechanism as that of epidermal cells reported.

\section{文献}

1) Allen, A.C. and Spitz, S. : Malignant melanoma ; Clinicopathological analysis of criteria for diagnosis and prognosis. Cancer, 6:1 45, 1953.

2) Ashikari, R., Park, K., Huvos, G. and Urban, J.A. : Paget's disease of the breast, Cancer, $26: 680 \sim 685$, 1970.

3) Becker, W. Jr., Fitzpatrick, T.B. and Montgomery, H. : Human melanogenesis: Cytology and histology of pigment cells (melanodendrocytes), Arch. Derm. \& Syphil, $65:$ 511 523, 1952.

4) Belcher, R. W. : Extramammary Paget's disease. Enzyme histochemical and electron mictroscopic study, Arch. Path., 94 : 59 64, 1972.

5) Birbeck, M.S.C., Mercer, E.H. and Barnicot, N.A. : The structure and formation of pigment granules in human hair, Exptl. Cell Res., 10 : 505 514, 1956.

6) Culberson, J. D. and Horn, R. C. Jr. : Paget's disease of the Nipple ; Review of 25 cases with special reference to melanin pigmentation, Arch. Surg., $72: 224 \sim 231$, 1956.

7) Demopoulos, R.I. : Fine structure of the extramammary Paget's cell, Cancer, $27:$ 1202 1210, 1971.

8) Klaus, S.N. and Snell, R.S. : The response of mammalian epidermal melanocytes in culture to hormones, J. Invest. Derm., 48 : 352 358, 1967.

9) Koss, L.G. and Brokunier, A. : Ultrastructural aspects of Paget's disease of the vulva, Arch. Path., $87: 592$ $\sim 600,1969$.

10) Lee, S.C., Roth, L. M., Ehrlich, C. and Hall, J.A. : Extramammary Paget's disease of the vulva, Cancer, $39: 2540 \sim 2549,1977$.

11) Masukawa, T., Kuzma, J. and Straumjord, J.V. : Cytologic detection of early Paget's disease of breast with improved cellular collection method, Acta Cytol., $19: 274 \sim 278,1975$.

12) McDivitt, R.W., Stewart, F.W. and Berg, J.W. : Atlas. Tumor of the breast, pp. $19 \sim 22$, AFIP. F.11, Washington, 1968.

13) Medenica, M., Sahihi, T. : Ultrastructural study of a 
case of extramammary Paget's disease of the vulva, Arch. Derm., 105 : 236 243, 1972.

14) Orr, J.W. and Parsh, D.J. : The nature of the nipple changes in Paget's disease, J. Pathol., Bacteriol., 84 : $201 \sim 208,1962$.

15) Paget, J. : Disease of the mammary areola preceding cancer of the mammary gland, St. Barth. Hosp. Rep., $10: 87 \sim 89,1874$.

16) Sagami, S. : Electron microscopic studies in Paget's disease, Med. J. Osaka Univ., 14 : 173 187, 1963.

17) Sagebiel, R.W.: Ultrastructural observations on epidermal cells in Paget's disease of the breast. Am. J.
Path., $57: 49 \sim 56,1969$

18）坂元吾偉, 菅野晴夫, 梶谷 鐶, 久野敬二郎, 深見敦夫: 乳房の Paget 病, 癌の臨, $19: 323 \sim 334,1973$.

19）清寺 真, 棚橋善郎：メラノサイトの微細構造と機能, 細 胞, $4: 16 \sim 25,1972$.

20) Toker, C. : Some observations on Paget's disease of the nipple, Cancer, $14: 653 \sim 672,1961$.

21）山田 喬, 清野良民, 糡部博史, 宇多康浩: 悪性黑色腫の 槑離細胞診, 日臨細胞誌, $2: 94 \sim 104,1963$.

22) Yamada, T., Itou, U., Watanabe, Y. and Ohashi, S. : Cytologic diagnosis of malignant melanoma, Acta Cytol., $16: 70 \sim 76,1972$. 